\title{
Design of Hypothetical Learning Trajectory (HLT) in Mathematics using motif of Anyaman Bambu
}

\author{
Suparman $^{1 *}$, Maryati ${ }^{2}$ \\ ${ }^{1,2}$ Universitas Ahmad Dahlan, Kota Yogyakarta, Yogyakarta, Indonesia \\ *Corresponding author: suparman@pmat.uad.ac.id
}

DOI: https://doi.org/10.37134/ajatel.vo19.no1.2.2019

Published: 05 June 2019

\begin{abstract}
Several previous research showed that students had difficulty in understanding the concept of transformation. Students are more likely to be introduced by using formula, and their learning is separate from the daily experience of students. This underlies the researcher to design a learning trajectory of learning transformation and to connect it with experience-based activities. The purpose of this research is to design of hypothetical learning trajectory in learning translation using motif of Anyaman Bambu as a starting point or learning context. The method used in this research is Design Research with three-step that is preliminary design, design experiment, and retrospective analysis. Design Research is a research method that has five characteristics, namely interventionist nature, process oriented, reflective component, cyclic character, and theory oriented. The subjects in this research were several samples of student's class VIII junior high school. Data collection techniques used in this study include video recording, documentation, written data, and observation. Data analysis carried out in this study is to compare the results of observation during the learning process with the Hypothetical Learning Trajectory that has been designed at the preliminary design stage. The results of this study indicate that in trans-geometric learning especially translational learning can be used learning design using local contexts such as culture or other things that are easily found in students' daily activities. This can help students to understand mathematical concepts easily, pleasantly, close to the daily activities of students and the students' imagination. Besides, it can facilitate students in solving problems encountered in students' daily lives.
\end{abstract}

Keywords: Anyaman Bambu, Design research, Hypothetical learning trajectory, Translation, Assessment

\section{INTRODUCTION}

Transformation is one of the concepts in learning mathematics at school that is widely applied in daily life. In Indonesia, material for transformation has been taught at the junior high school level. However, there are still students who have difficulty understanding the basic concepts of transformation (Ada, Tuba, $\&$ Kurtulus, 2010). In fact, material transformation is very important to learn in school because this concept underlies other concepts such as function and symmetry (Hollebrands, 2003).

Transformation material learned at the junior high school level is divided into four topics, namely translation, reflection, rotation, and dilation. The translation is a transformation that moves every point in a field according to a certain distance and direction. The reflection is one type of transformation that moves each point on afield using the mirror image. The rotation is a transformation that moves points by rotating the points as far as $\theta$ to a central point of rotation. The dilation is a transformation that changes the distance of points with certain multipliers to a certain point (Maryati \& Prahmana, 2019).

The results of the PISA study (Program for International Student Assessments) analyzed by Stacey (2011) show that Indonesian students are still having difficulties in applying mathematical concepts in solving problems related to daily life. This is one of them caused by the process of learning mathematics in schools which tends to be taught practical formulas and has not connected mathematics with culture and daily activities (Arisetyawan, Suryadi, Herman, \& Rahmat, 2014). In fact, mathematics is everywhere and experienced and practiced by every culture and must be included in the school mathematics curriculum (Christina, Ilukena, \& Sindano, 2017; Muhtadi, Sukirwan, Warsito, \& Prahmana, 2017 ; Fouze \& Amit, 2018). Besides, cultural diversity around students can be integrated into mathematics learning in class (Chahine, 2011; Ogunkunle \& George, 2015; Rosa, et al. 2016). 
Sembiring, Hadi, \& Dolk (2008) state that the problem of mathematics learning that has not connected with daily life finally motivates Indonesian mathematics educators to find learning methods. The learning method is Pendidikan Matematika Realistik Indonesia (PMRI) which is a result of the adaptation of Realistic Mathematics Education (RME) and has been developed following the context, cultural values, or local wisdom in Indonesia (Lestariningsih, Putri, \& Darmawijoyo, 2015). PMRI is not only concerned with the final results, but more emphasis on the processes that occur during learning takes place (Sembiring et al., 2008). Besides, PMRI is also oriented to technical capabilities in the direction of reforming mathematics education based on solving problems in everyday life.

Reform of realistic mathematics education is carried out on two pillars, first, the ability of the teacher to create a problem-oriented classroom culture and to invite students in interactive learning and second, to design learning activities that can encourage the rediscovery of mathematics (Heuvel-panhuizen \& Drijvers, 2014). Besides, the development of PMRI is one of them carried out with research that aims to improve the practice of learning in the classroom through interactive analysis of expectations of what will happen in the classroom and its implementation, and the research is design research (Cobb \& Gravemeijer, 2006).

Therefore, as an innovation in mathematics learning and as an implementation of the 2013 curriculum that is oriented to mathematical relevance to the conditions of reality and culture of students, researchers create a translational learning design using the motif of Anyaman Bambu as the starting point or context in learning. This context is chosen because it is close to students and easily found in students' daily lives. So, through this design, it is expected to be an innovation in mathematics learning that can facilitate students in understanding translational concepts and being able to solve everyday problems related to the concept and have cultured characters.

Yogyakarta is one of the cities in Indonesia which is famous as a city of culture. One culture that is still preserved is the making of Anyaman Bambu. According to Maryati and Prahmana (2019), the motif of Anyaman Bambu can make it easier for students to learn the concept of transformation. To prepare students more easily understand mathematical concepts, especially in motifs of Anyaman Bambu, a learning design can be designed. The learning design uses motifs of Anyaman Bambu as the context and uses activities to draw motifs of Anyaman Bambu and introduces the concept of transformation.

In designing learning activities for a particular topic, the teacher must have hypotheses and be able to consider the reactions of students for each stage of the learning trajectory to the learning objectives implemented. In the view of Gravemeijer \& Van Eerde (2006), students are allowed to construct and develop their ideas and thoughts when constructing mathematics. The teacher can choose the appropriate learning activities as a basis to stimulate students to think and act when constructing mathematics concept (Prahmana, Kusumah \& Darhim, 2017). In the process of the activity, the teacher must anticipate what mental activities might arise from students while paying attention to the learning objectives. Imagery and anticipation are called hypothetical learning trajectory, so HLT can be interpreted as a hypothesis or prediction of how students' thinking and understanding develop in learning activities (Prahmana \& Kusumah, 2016).

Gravemeijer (2004) states that HLT consists of three main components, namely (1) the purpose of mathematics learning for students; (2) learning activities and devices/media used in the learning process; and (3) the conjecture of the learning process how to know students' understanding and strategies that arise and develop when learning activities are carried out in the classroom. In the preliminary design phase, HLT serves as a guideline for teaching materials to be developed. Furthermore, at the stage of teaching trials, HLT serves as a guide for educators and researchers in teaching activities, interviews, and observations (Prahmana \& Kusumah, 2016).

This study aims to improve the practice of learning in the classroom through interactive analysis of expectations of what will happen in the class-room and its implementation.

\section{METHOD}

The research method used in this study is Design Research, which is the right way to answer research questions and achieve research objectives starting from initial design, teaching experiments, and retrospective analysis (Maryati \& Prahmana, 2019). Design research is a research method that has five characteristics, namely nature interventionist, process-oriented, reflective component, cyclic character, and theory-oriented (Prahmana et al., 2017). Plomp (2013) defines design re-search as an appropriate method for developing solutions (solutions) based on research that is appropriate for developing or 
validating a theory about the learning process and the like.

The subjects in this research were several samples of student's class VIII junior high school. Data collection techniques used in this study include video recording, documentation, written data, and observation. Data analysis carried out in this study is to compare the results of observations during the learning process with the Hypothetical Learning Trajectory that has been designed at the preliminary design stage.

Design research is also interpreted as a method that aims to develop Local Instructions Theory by collaborating between researchers and teachers to improve the quality of learning (Mckenney \& Reeves, 2018). The following stag-es in this study, referring to the stages of design research proposed by Plomp (2013):

\section{Stage 1: Preliminary design}

The preliminary design phase aims to develop a sequence of learning activities and design instruments to evaluate the learning process. In this study, a literature study was carried out on the translation concepts in material geometry transformation, PMRI, and analysis of translation material in Indonesian mathematics curriculum, so that it can be formed as a conjecture or alleged student thinking. Besides, in this stage, the Hypothetical Learning Trajectory (HLT) is de-signed to be formulated into learning objectives and tools to assist learning. In this case, the conjecture functions as a guideline that appears and develops in each learning activity and is flexible and can be revised during the experiment design stage or pilot stage.

\section{Stage 2: Design experiment}

The design experiment phase is to try out the trajectory of learning that has been designed in the learning process. This stage aims to explore and predict students' strategies and thoughts during the actual learning process. The steps in the design experiment are di-vided into two phases, namely the stage of the teaching experiment and the pilot experiment. The stages carried out in this study were the steps of the teaching experiment that were tried out into several samples from the research subjects during the experiment design stage or the trial stage. The stages carried out in this study are the stages of the teaching experiment that were tried out into several samples from the research subjects.

\section{Stage 3: Retrospective Analysis}

At this stage, the conjecture in HLT is compared with the results of the design experiment stage. So, from the results of this analysis can produce a description of the learning trajectory in translation learning using the motif of Anyaman Bambu.

\section{RESULTS AND DISCUSSION}

The results obtained in this study are in the form of HLT design in which there is a learning path in junior high school level translation learning using the motif of Anyaman Bambu as the starting point or context in learning. The researcher describes the data or results obtained from each research stage as follows:

\section{Preliminary Design}

In the preliminary design stage, the researcher implemented the initial idea about the use of the context of Anyaman Bambu in translation learning in the material of geometry transformation at the junior high school level. This Anyaman Bambu is selected based on research Bakar, Kramer, Bordas, \& Rabczuk (2013) which states that in Anyaman there is an implementation of the concept of geometry transformation. Besides, traditional woven crafts can stimulate students to develop their knowledge of mathematical concepts (Haris \& Putri, 2011).

The development of HLT in each learning activity is the most crucial part in designing student learning 
activities. The design is in-separable from the learning trajectory that contains learning plans from the material that is taught. In this case, the learning trajectory is a concept map that students will go through during the learning process. The learning trajectory used in this study is an understanding of translation concepts utilizing the context of Anyaman Bambu. The process starts by drawing the motif of Anyaman $B a m b u$, then from the process, an understanding of the relationship between the starting point and the endpoint of the translation results will be obtained. Furthermore, after reaching this understanding, a translation formula will be found for specific directions and degrees and its application in solving everyday problems as presented in Figure 1.

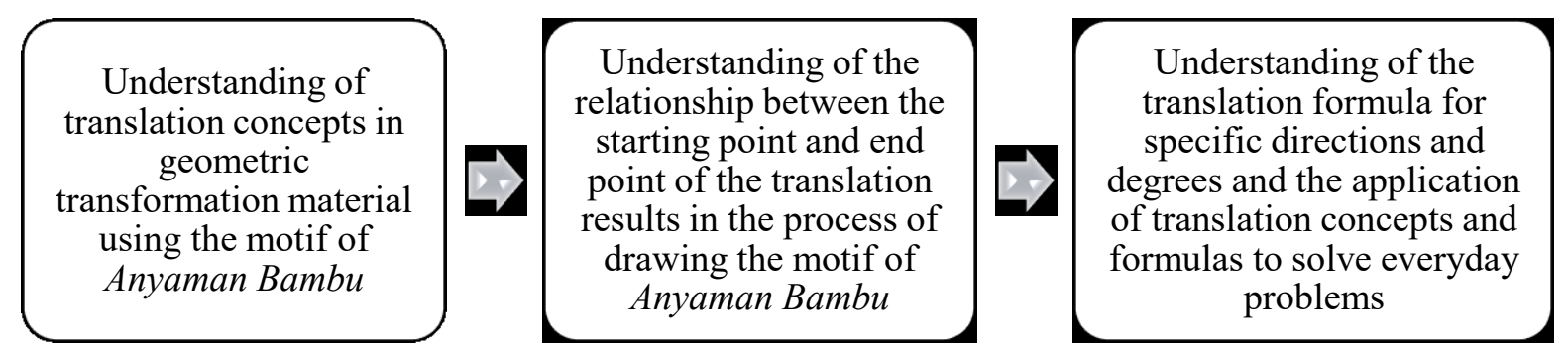

Figure 1. Learning Trajectory of Translation Learning in Junior High School Level

A set of translational learning activities based on learning trajectory and the results of student thinking are hypothesized in HLT. This aims to achieve students' understanding of translation and be able to apply it to problems encountered in everyday life. The relationship between learning pathways, activities, and the achievement of translation learning designed to be HLT can be seen in Figure 2 .

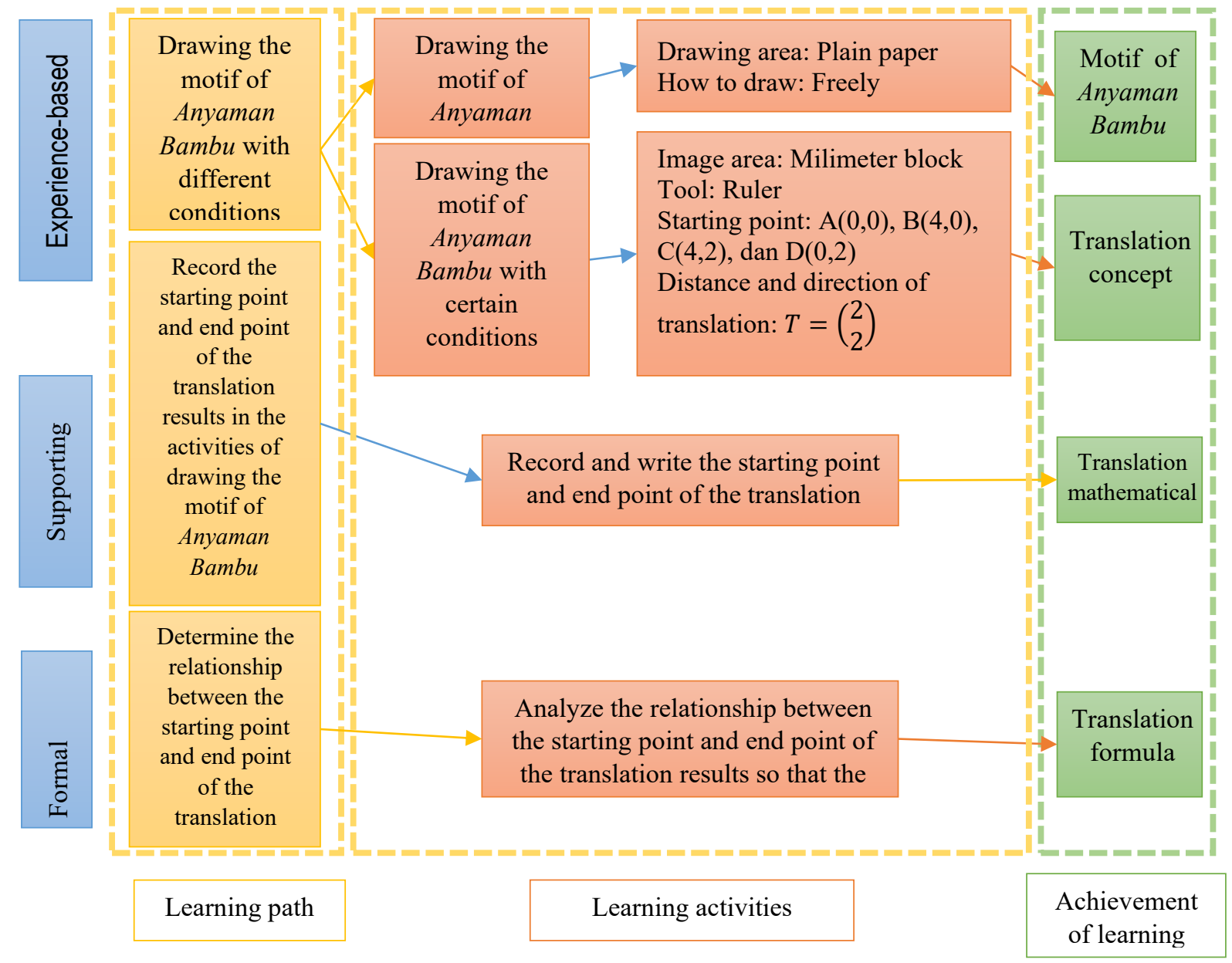

Figure 2. The Design of Hypothetical Learning Trajectory (HLT) in Learning Junior High School Level 
Based on the HLT described in Figure 2, the general student learning trajectory obtained in junior high school translation learning using the motif of Anyaman Bambu is illustrated in the iceberg form in Figure 3.

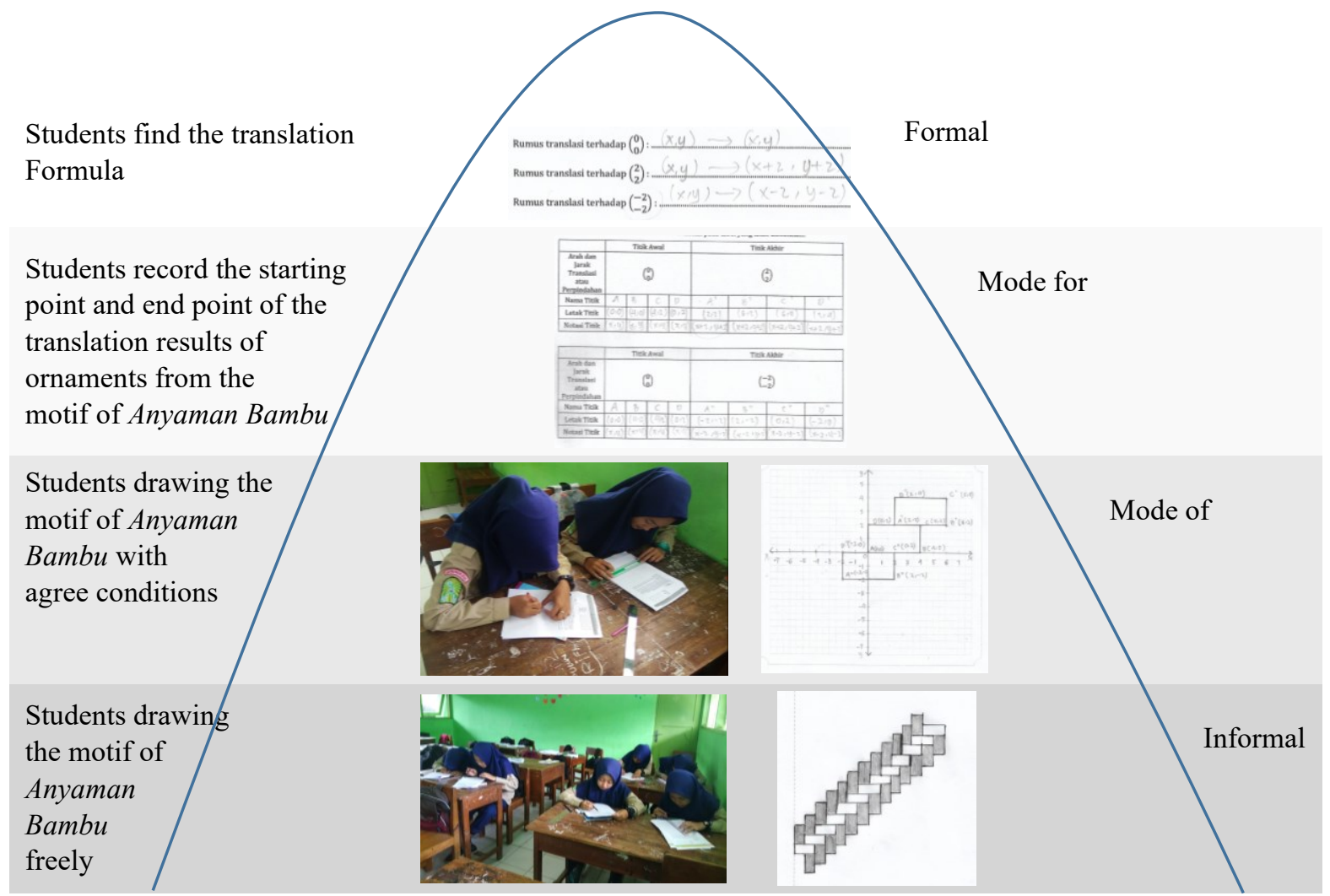

Figure 3. Iceberg HLT of Translation Learning in Junior High School Level

Based on the HLT that has been designed, the translation learning conjunctions can be obtained which can be seen in Table 1.

Table 1. Translation Learning Conjunction Using the Motif of Anyaman Bambu

\begin{tabular}{|c|c|c|c|}
\hline Stage & $\begin{array}{l}\text { Activities } \\
\text { to- }\end{array}$ & $\begin{array}{l}\text { Description of } \\
\text { Activities }\end{array}$ & Conjecture \\
\hline Informal & 1 & $\begin{array}{l}\text { Drawing the motif of } \\
\text { Anyaman Bambu freely }\end{array}$ & $\begin{array}{l}\text { 1. Students are familiar with the motif of Anyaman Bambu } \\
\text { and can describe it } \\
\text { 2. Students do not yet know the motif of Anyaman Bambu } \\
\text { and cannot yet describe it } \\
\text { 3. Students do not yet know that in drawing a motif of } \\
\text { Anyaman Bambu, they have used the translation concept } \\
\text { 4. Students have realized that in drawing motif of Anyaman } \\
\text { Bambu have used translational concepts }\end{array}$ \\
\hline Mode of & 2 & $\begin{array}{l}\text { Drawing the motif of } \\
\text { Anyaman Bambu with } \\
\text { certain conditions }\end{array}$ & $\begin{array}{l}\text { 1. Students can move the ornament from the motif of } \\
\text { Anyaman Bambu correctly and get the right points } \\
\text { 2. Students have not been able to move the ornaments from } \\
\text { the motif of Anyaman Bambu correctly and have not } \\
\text { gotten the right points }\end{array}$ \\
\hline Mode for & 3 & $\begin{array}{l}\text { Record the starting } \\
\text { point and end point of } \\
\text { the translation results } \\
\text { in drawing the motif of } \\
\text { Anyaman Bambu }\end{array}$ & $\begin{array}{l}\text { 1. Students can record the starting point and end point of the } \\
\text { translation results of ornaments from the motif of } \\
\text { Anyaman Bambu correctly } \\
\text { 2. Students have not been able to record the starting point } \\
\text { and end point of the translation results of the ornament } \\
\text { from the motif Anyaman Bambu correctly }\end{array}$ \\
\hline
\end{tabular}




\begin{tabular}{ccll}
\hline Stage & $\begin{array}{c}\text { Activities } \\
\text { to- }\end{array}$ & \multicolumn{1}{c}{$\begin{array}{c}\text { Description of } \\
\text { Activities }\end{array}$} & Conjecture \\
\hline Formal & 4 & $\begin{array}{l}\text { Determine } \\
\text { relationship of the } \\
\text { starting point and end } \\
\text { point of the translation } \\
\text { results in drawing the } \\
\text { motif of Anyaman } \\
\text { Bambu }\end{array}$ & $\begin{array}{l}\text { 1. Students can find the relationship between the starting } \\
\text { point and end point of the ornamental translation results } \\
\text { from the motif of Anyaman Bambu and find the } \\
\text { translation formula }\end{array}$ \\
$\begin{array}{l}\text { 2. Students have not been able to find the relationship } \\
\text { between the starting point and end point of the } \\
\text { ornamental translation results from the motif of Anyaman } \\
\text { Bambu and have not found the translation formula }\end{array}$ \\
\hline
\end{tabular}

\section{Design Experiment and Retrospective Analysis}

At this stage, the researcher conducted a learning trajectory experiment that had been designed for several junior high school class VIII students. Next, the researcher did a retrospective analysis of the results of the experiment obtained in the experiment design stage. There are 4 activities carried out in the experiment design stage and classified in several stages, namely activities in the informal stage, mode of, mode, and formal stages as follows:

\section{Stage Informal}

At this stage of the activities carried out is the first activity, students observe of Anyaman Bambu images contained on the Student Activity Sheet 1 (LAS 1). Master told about the philosophy and the meaning contained in the motif of Anyaman Bambu for building student character cultured. After that, to get a common perception of the students, teachers asked students to answer questions that exist in the LAS 1 by drawing the motif of Anyaman Bambu freely in accordance with the understanding there is in the minds of students.

After the students have finished drawing the motif of Anyaman Bambu, then the teacher asks the students to reveal how to make the motif of Anyaman Bambu. At this stage several different perceptions of students were found, some students revealed that in drawing the motif of Anyaman Bambu it was begun by drawing a rectangular shape then drawing a similar shape beside it with different positions or being shifted slightly upwards so that it finally formed like stairs. Besides, there were also students who revealed that in drawing the motif of Anyaman Bambu it could be done by drawing a ladder formed from a rectangular pile, as can be seen in Figure 4.

After students drawing the motif of Anyaman Bambu freely, then the teacher and students discuss how to drawing the motif of Anyaman Bambu and practice again how to drawing the motif of Anyaman $B a m b u$ to obtain the same perception between teachers and students, this is done to facilitate the implementation of activities in the next stage. 

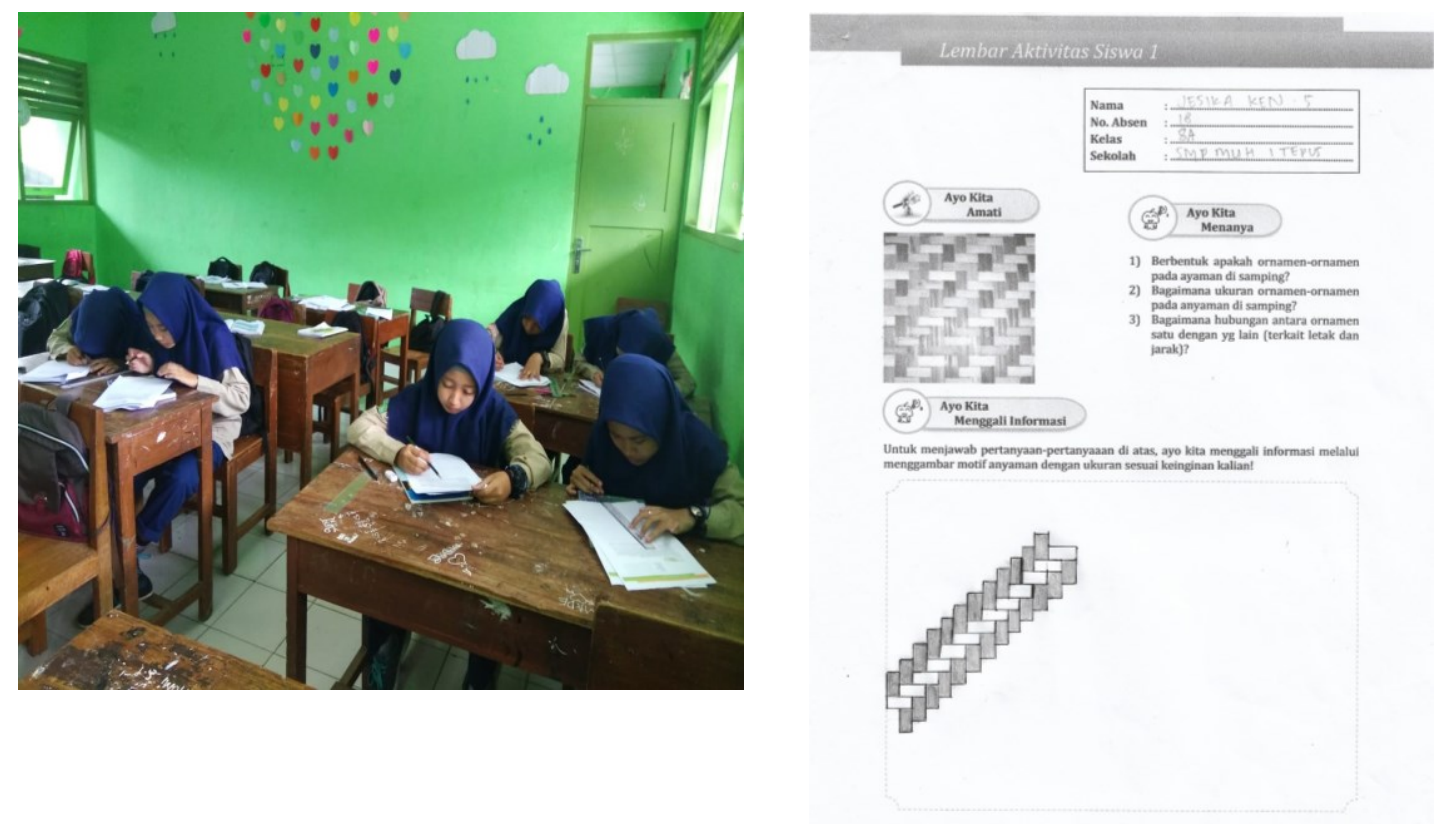

Figure 4. Student Activities Drawing the Motif of Anyaman Bambu

In this stage, students are familiar with the motif of Anyaman Bambu because the motif is part of the culture of students in Javanese culture and is easily found by students in everyday life such as on a simple house wall. So, students are easy to imagine and de-scribe. When drawing the motif of Anyaman Bambu students still did not realize and understand that in drawing the motif of Anyaman Bambu students had applied the translation concept. This under-standing was developed through discussions between teachers and students about the concepts that can be learned from the process of drawing the motif of Anyaman $B a m b u$. The end result, students realize that in drawing the motif of Anyaman Bambu can be done by moving or sliding an ornament that has a rectangular shape to a certain distance and direction.

\section{Stage Mode of}

The activities carried out at this stage are the second activity, drawing the Anyaman Bambu motif with the agreed conditions. At this stage, students have gained an understanding derived from previous activities that in drawing the motif of Anyaman Bambu can be done by moving an ornament to a certain distance and direction. Then, the teacher invites students to make an agreement to drawing the motif of Anyaman Bambu using millimeter block paper that has been provided in LAS 2. Students begin the activity by creating a Cartesian field. Furthermore, students drawing the motif of Anyaman Bambu starting from making points $\mathrm{A}(0,0), \mathrm{B}(4,0), \mathrm{C}(4,2)$, and $\mathrm{D}(0,2)$ in the Cartesian plane, the four points are connected to form one rectangular ornaments.

Students make an ornament again whose size is the same as the distance and direction of $\operatorname{shift} T=$ $\left(\begin{array}{l}2 \\ 2\end{array}\right)$, meaning shifting the ornament to the right is two units and upward is two units apart. After that, students make another ornament whose size is equal to distance and direction of $\operatorname{shift} T=\left(\begin{array}{l}-2 \\ -2\end{array}\right)$, meaning shifting ornaments to the left is two units and downward is two units apart. The tool used in this stage is a ruler. This activity is carried out to obtain students' understanding of the translation concepts in the cartesius field and the effect of sliding distance and sliding direction on translation results. In this second activity, students draw three Anyaman Bambu ornaments using examples of ornaments that have been provided using paperboard, the ornaments are drawn on the Cartesian quadrant I coordinate to get a positive starting point. 
At this stage, the endpoint of the ornament is obtained or the starting point is point $\mathrm{A}(0,0), \mathrm{B}(4,0), \mathrm{C}(4,2)$, and $\mathrm{D}(0,2)$. This starting point is then shifted to the right as much as two units and upwards to two units so that the translation result points are obtained, namely point $\mathrm{A}^{\prime}(2,2), \mathrm{B}^{\prime}(6,2), \mathrm{C}^{\prime}(6,4)$, and $\mathrm{D}^{\prime}(2,4)$. After that, the starting point is also shifted to the left as much as two units and down two units so that the translation result is point $\mathrm{A}^{\prime \prime}(-2,-2), \mathrm{B}^{\prime \prime}(2,-2), \mathrm{C}^{\prime \prime}(2,0)$, and $\mathrm{D}^{\prime \prime}(-2,0)$. The points of translation results can be seen in Figure 5.

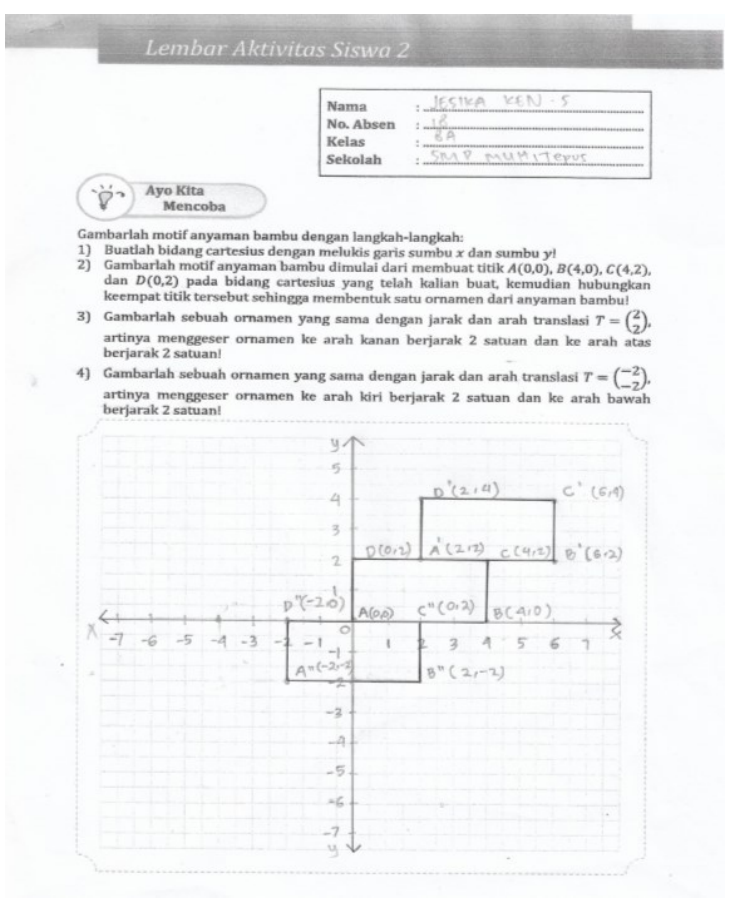

Figure 5. Student Work Results in Drawing the Motif of Anyaman Bambu in the Cartesian coordinate Field

\section{Stage mode for}

Activities carried out in the mode for phase, namely the third activity, students do data collection of the translation starting point and end point of the translation results in the table in LAS 3 that has been provided. Students record the starting point and end point. After that, the ordinate and abscissa values at each point are re-placed by letters $\mathrm{x}$ and $\mathrm{y}$. Then, the distance and direction of the slide are symbolized by letters $a$ and $b$. This is done with the aim that students are easy to find the relationship between the starting point and the endpoint of the translation result. After completing recording these points on the table, then the teacher and students discuss the relationship between the starting point and the endpoint of the translation results. The results of student work in recording the starting point and end point of the translation results can be seen in Figure 6. 


\section{Lembar Aktivitas Siswa 3}

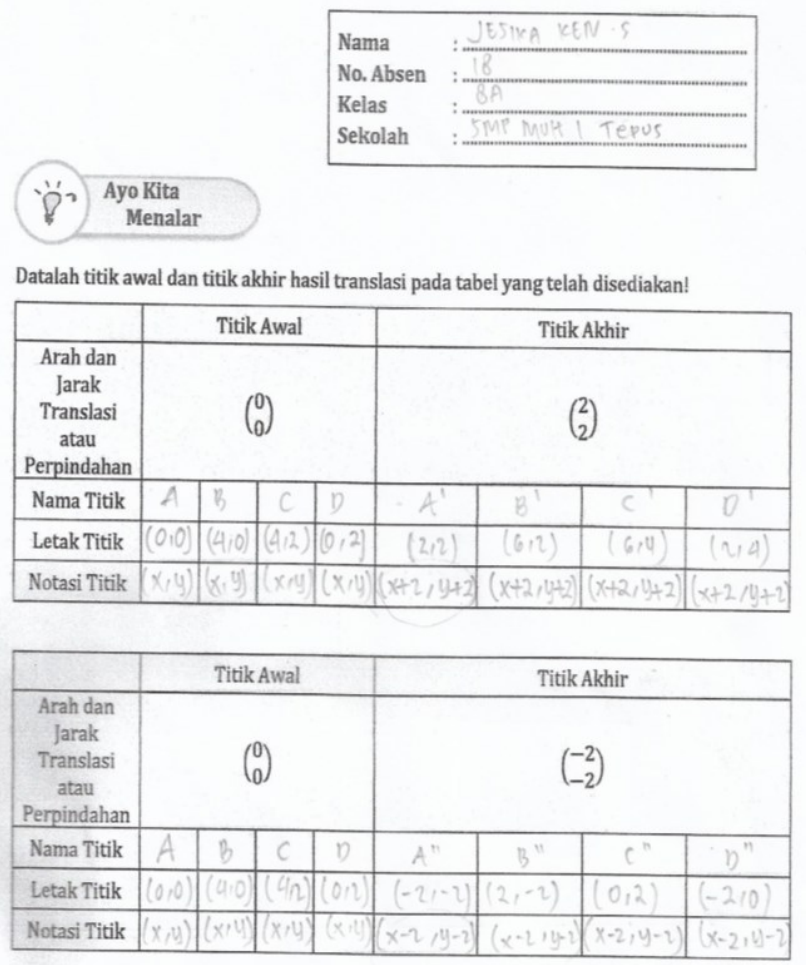

Figure 6. Student Work Results in Data Collection of Starting Points and End-points

\section{Stage formal}

At this stage, students connect data from the starting point and end point so that a mathematical model of the relationship is obtained. The teacher invites students to discuss the mathematical model found by trying to use the model in translating the endpoints of translation results $T=\left(\begin{array}{l}2 \\ 2\end{array}\right)$ into LAS 3 tables with the same distance and direction of translation, that is $T=\left(\begin{array}{l}2 \\ 2\end{array}\right)$, without the help of millimeter blocks and cartesian coordinates so that other points of the translation results are obtained. Furthermore, students are asked to can move the endpoint of the translation results $T=\left(\begin{array}{l}-2 \\ -2\end{array}\right)$ into LAS 3 table with the same distance and direction of translation, that is $T=\left(\begin{array}{l}-2 \\ -2\end{array}\right)$, without the help of millimeter blocks and cartesian coordinates so that other points are obtained from the translation results. The points of the translation result are depicted in the cartesian plane. Appar-ently, obtained an ornamental pattern from Anyaman Bambu as in LAS 1. Then the teacher invites students to conclude that the math-ematical model found in the drawing process of the motif of Anyaman Bambu is a translation formula of a point towards a par-ticular direction and direction. The results of the students' work in finding the translation formula in the process of drawing the motif of Anyaman Bambu can be seen in Figure 7. 


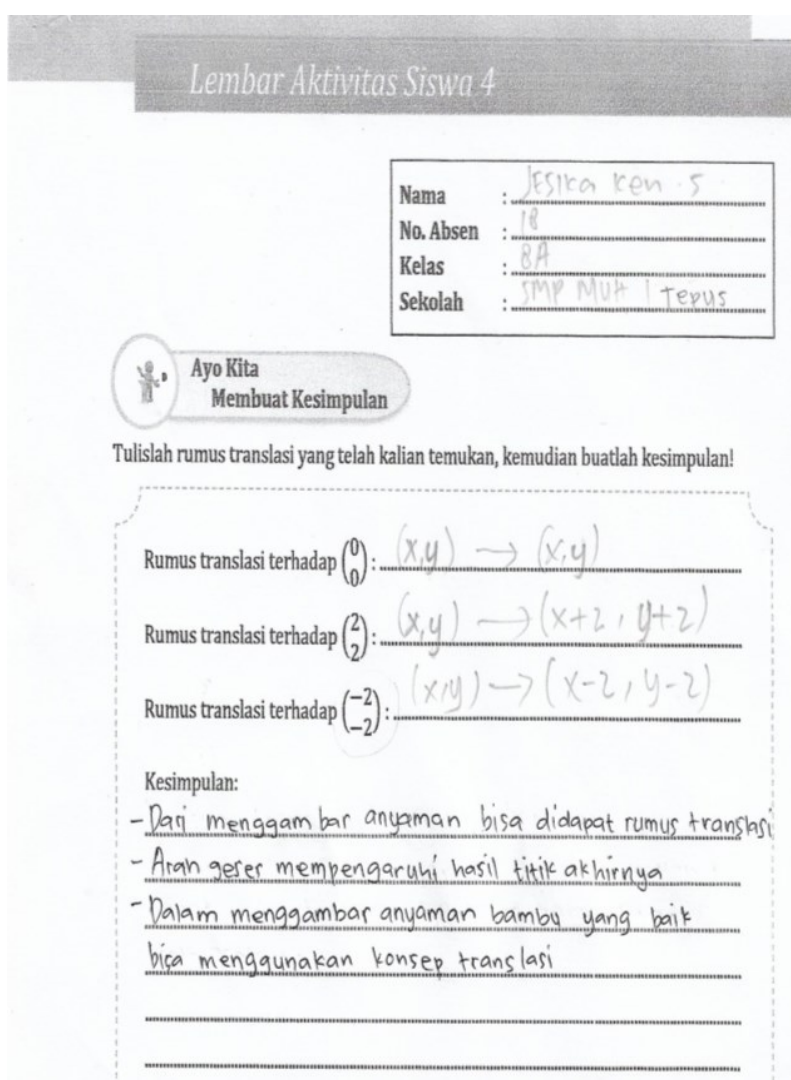

Figure 7. Student Work Results in Finding Translation Formulas in the Drawing Process of Anyaman Bambu

Next, the teacher guides students to complete other questions that are often encountered in the daily lives of students using concepts and translation formulas that have been approved by students. In this final stage, students have discussed the concepts and translation equations, and the things that affect translation are the translation distance and the direction translated by students and can use transla-tion concepts and formulas in solving problems encountered in everyday life. In general, each learning activity is interpreted interac-tively, and students present answers and explain the reasons for the answers given and are actively involved in the discussion.

\section{CONCLUSION}

The results of this study indicate that in trans-geometric learning especially translational learning can be used learning design using local contexts such as culture or other things that are easily found in students' daily activities. This can help students to understand mathematical concepts easily, pleasantly, close to the daily activities of students and the students' imagination. Besides, it can facilitate students in solving problems encountered in students' daily lives.

This research is in line with the reform of mathematics education which was initiated by Indonesian mathematics educators through Pendidikan Matematika Realistik Indonesia (PMRI) to create learning methods that are not only concerned with the final results, but rather emphasize the processes that occur during learning and are oriented towards problem solving in daily life and oriented to the rediscovery of mathematical concepts.

In addition, several researchers have also made mathematical using the PMRI approach such as learning design multiplication operation using the context of Tepuk Bergambar games, learning design measurement area using the context Anyaman, learning design number operations using Satu Rumah games. Therefore, the role taken from the results of this study is to add to the study of mathematical learning design, namely the design of translation learning using the motif of Anyaman Bambu. 


\section{REFERENCES}

Ada, Tuba, \& Kurtulus, A. (2010). Students' misconceptions and errors in transformation geometry. International Journal of Mathematical Education in Science and Technology, 41(7), 2010.

Arisetyawan, A., Suryadi, D., Herman, T., \& Rahmat, C. (2014). Study of Ethnomathematics : A lesson from the Baduy Culture. International Journal of Education and Research, 2(10), 681-688.

Bakar, I.A.A., Kramer, O., Bordas, S., \& Rabczuk, T. (2013). Optimization of elastic properties and weaving patterns of woven composites. Composite Structures, 100, 75-591.

Chahine, I.C. (2011). Beyond Eurocentrism: Situating Ethnomathematics Within the History of Mathematics Narrative. International Journal for Studies in Mathematics Education, 4(2), 35-48.

Christina, U., Ilukena, A., \& Sindano, G. (2017). Exploring How Modern Sciences Impede the Development of Indigenous Knowledge (IK) [Ethno-science and Ethno-Mathematics] in the Kavango East Region: A Case Study. Journal for Studies in Humanities and Social Sciences, 6(2), 68-88.

Cobb, P., \& Gravemeijer, K. (2006). Educational Design Research. Routledge, 29-63. https://doi.org/10.1016/j.ijbiomac.2013.09.048

Fouze, A. Q., \& Amit, M. (2018). On the importance of an ethnomathematical curriculum in mathematics education. Eurasia Journal of Mathematics, Science and Technology Education, 14(2), 561-567. https://doi.org/10.12973/ejmste/76956

Haris, D., \& Putri, R. I. I. (2011). The Role of Context in Third Graders ' Learning of Area Measurement. Journal on Mathematics Education, 2(1), 55-66.

Heuvel-panhuizen, M.V.D., \& Drijvers, P. (2014). Realistic mathematics education. Encyclopedia of Mathematics Education, 521-525. https://doi.org/10.1007/978-94-007-4978-8

Hollebrands, K.F. (2003). High school students ' understandings of geometric transformations in the context of a technological environment. The Journal of Mathematical Behavior, 22(1), 55-72.

Lestariningsih, Putri, R.I.I., \& Darmawijoyo. (2015). The Legend of Kemaro Island for Supporting Students in Learning Average. Journal on Mathematics Education, 3(2), 165-174.

Maryati, \& Prahmana, R.C.I. (2019). Ethnomathematics: Exploration of the Muntuk Community. International Journal Of Scientific \& Technology Research, 8(6), 47-49.

Mckenney, S., \& Reeves, T. C. (2018). Conducting Educational Design Research. New York: Routledge.

Muhtadi, D., Sukirwan, Warsito, \& Prahmana, R. C. I. (2017). Sundanese Ethnomathematics: Mathematical Activities in Estimating, Measuring, and Making Patterns. Journal on Mathematics Education, 8(2), 185-198.

Nasrullah, \& Zulkardi. (2011). Building Counting by Traditional Game: A Mathematics Program for Young Children. Indonesian Mathematical Society Journal on Mathematics Education, 2(1), 4154. Retrieved from http://search.proquest.com/docview/1773217206?accountid=8330

Ogunkunle, R.A., \& George, N.R. (2015). Integrating Ethnomathematics Into Secondary School Mathematics Curriculum For Effective Artisan Creative Skill Development. European Scientific Journal, 11(3), 386-397. https://doi.org/10.1016/j.jsat.2007.03.006

Plomp, T. (2013). Educational Design Research: An Introduction. In Educational Design Research. Enschede: Netherlands Institute for Curriculum Development (SLO). https://doi.org/10.12968/bjon.2012.21.14.839

Prahmana, R.C.I., \& Kusumah, Y.S. (2016). The Hypothetical Learning Trajectory on Research in Mathematics Education Using Research-Based Learning. Pedagogika, 123(3), 42-54.

Prahmana, R.C.I., Kusumah, Y.S., \& Darhim. (2017). Didactic trajectory of research in mathematics education using research-based learning Didactic trajectory of research in mathematics education using research-based learning. Journal of Physics: Conference Series, 893(1), 012001.

Prahmana, R.C.I., Zulkardi, \& Hartono, Y. (2012). Learning Multiplication Using Indonesian Traditional game in Third Grade Rully Charitas Indra Prahmana, Zulkardi, Yusuf Hartono. Journal on Mathematics Education, 3(2), 115-132.

Rosa, M., D’Ambrosio, U., Orey, D. C., Shirley, L., Alangui, W. V., Palhares, P., \& Gavarrete, M. E. (2016). Current and Future Perspectives of Ethnomathematics as a Program. Switzerland: Springer. https://doi.org/10.1007/978-3-319-30120-4

Sembiring, R. K., Hadi, S., \& Dolk, M. (2008). Reforming mathematics learning in Indonesian classrooms 
Design of Hypothetical Learning Trajectory (HLT) in Mathematics using motif of Anyaman Bambu

through RME. International Journal on Mathematics Education, 40(6), 927-939. https://doi.org/10.1007/s11858-008-0125-9

Stacey, K. (2011). The PISA View of Mathematical Literacy in Indonesia. Journal on Mathematics Education, 2(2), 95-126. https://doi.org/10.22342/jme.2.2.746.95-126 